EISSN: 2706-7955 ISSN: 2077-4605

DOI: 10.36632/mejar/2021.10.1.7

Journal homepage: www.curresweb.com

Pages: 99-109

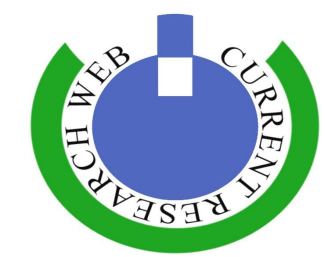

\title{
Impact of Inclusion Heat-Treated Jatropha Meal in Diets on Performance of Fattening Lambs
}

\author{
Yasser A. A. El-Nomeary ${ }^{1}$, Wafaa M.A. Ghoneem ${ }^{2}$, Mohamed A. Hanafy ${ }^{2}$, Hashem H. \\ Abd El-Rahman', Adel E.M. Mahmoud ${ }^{2}$ and Alaa Y. K. Emam ${ }^{1}$ \\ ${ }^{I}$ Department of Animal Production, National Research Centre, 33 El-Bohouth St., Dokki, Giza, Egypt. \\ Post code: 12622. \\ ${ }^{2}$ Department of Animal Production, Faculty of Agriculture, Cairo University, 12613 Giza, Egypt.
}

Received: 19 November 2020 Accepted: 20 January $2021 \quad$ Published: 30 January 2021

\begin{abstract}
This study aims to investigate the effect of substitution cottonseed meal (CSM) by heated jatropha meal (HJM) with $0,30,45$, and $60 \%$ in sheep rations. Growth performance, rumen fluid, blood properties and economic efficiency of lambs were also evaluated. Twenty four Barki lambs with an average weight of $32.9 \mathrm{~kg}$ were randomly assigned to 4 groups ( 6 animals of each). The first group fed a control ration containing concentrate feed mixture (CFM) + peanut vines hay. The $2^{\text {nd }}, 3^{\text {rd }}$, and $4^{\text {th }}$ groups fed the control ration with replacing cottonseed meal by heated jatropha meal at 30, 45, and $60 \%$. Results: The control group recorded the best average daily weight gain, followed by the R2 group (192.77 vs. $191.10 \mathrm{~g}$ ) compared to R3 and R4 groups. Low ammonia nitrogen and total volatile fatty acids were observed in all different HJM groups compared to the control group. Animals were given rations containing 45, and 60\% HJM (R3 and R4) showed low total dry matter intake and average daily weight gain. The concentration of serum total protein was not significantly affected by the inclusion of HJM in experimental rations. Feed cost was decreased in R4, R3, and R2 groups, respectively than the control group. At the same time economic efficiency and relative economic efficiency was higher in R2 (HJM) as compared with the other groups. Conclusion: It possible to replace the cottonseed meal with $30 \%$ heated jatropha meal in lambs rations without any negative impacts on growth performance, decreased feed cost improved economic efficiency and feed use parameters for lambs.
\end{abstract}

Keywords: Jatropha curcas, Performance, Lambs and feed conversion, Blood characteristics and economic efficiency.

\section{Introduction}

The production of sheep and goats is the lowest development that differs from other livestock industries in Egypt. In sheep production, feed industry costs are the highest cost of production requirements may represent $70-80 \%$ of costs. The problem of the lack of feed for livestock is a growing problem worldwide. Feeding is a significant factor in sheep growth; proper growth and reproductive maturity need to share various nutrients. The nutritional gap between demand and supply in protein supplements for livestock feeding can be bridged due to the vital role resulting from the use of agrobased industrial products. Therefore, new alternative sources of protein for animal feeding have been and continue to result from animal nutritionists' research (Annongu et al., 2010).

Jatropha curcas from the Euphorbiaceae family is a multipurpose tree. Jatropha curcas was grown in Egypt in different areas. Jatropha has medicinal properties, and its oilseeds have great economic importance. Jatropha is drought-resistant and grows even in arid lands (Moore et al., 2011). Jatropha meal (the residue extracted with solvents obtained after removing biodiesel from jatropha seeds) is one such protein-rich potential for ruminant feeding ( 22 to $45 \% \mathrm{CP}$ ). However, the existence

Corresponding Author: Yasser A. A. El-Nomeary, Department of Animal Production, National Research Centre, 33 El-Buhouth St., Dokki, Giza, Egypt. Postcode: 12622.

E-mail: elnomeary@yahoo.com 
of anti-nutritional factors viz. esters of phorbol, lectin, saponin, trypsin inhibitors, etc. (Makkar et al. 2008; Rakshit et al., 2008) limit their use as a feed ingredient in ruminant feeds. However, they can be treated to reduce anti-nutritional factors and be useful as a feed supplement for livestock (Katole et al. 2011; Sudake et al., 2013). The phorbol ester is the most toxic compound of all of these compounds. These anti-nutritional compounds must be isolated either physically using heat treatment or chemically by extraction to use them as a source of protein in the diet. Physical, chemical, and biological methods lead to removing these substances and neutralizing their effects (Belewu and Sam 2010; Abo El-Fadel et al., 2011). Physical therapy with heating in the autoclave is likely to reduce antitrypsin and lemans in the seed meal (Aderibigbe et al., 1997).

The level of anti-nutritional compounds in jatropha was reduced to $75 \%$ by mixing heat treatment with sodium hypochlorite and sodium hydroxide as a chemical treatment (Haas and Mittelbach 2000). Sterilization, roasting, and germination are among the treatment methods to improve the nutritional properties of plant seeds (Ojediran et al. 2014). Michael et al. (2019) found that roasting recorded a greater decrease in the concentration of anti-nutritional factors among the treatments used. Antyev et al. (2017) and Duwa et al. (2002) reported a similar result when they subjected seeds to different treatment methods and a marked decrease in trypsin inhibitors. Saponins, oxalate, and phytic acid also showed a decline in concentration.

The aim of this study is to investigate the impact of heated jatropha meal on animal performance, some measurements of rumen fluid and blood parameters of growing fattening lambs.

\section{Methods}

This study was carried out at the Nubaria Experimental Station, Abd El-Moneam Riad Village, Nubaria City and in the Laboratories of Animal Production Department, National Research Centre in Egypt, from October to December 2018.

The present work was done to execute the best treatments found in the earlier work (heated jatropha meal, Alaa et al., 2020) to be applied in feeding trials with fattening lambs. Rumen fluid parameters and blood characteristics were determined. Economic efficiency has also been calculated.

\subsection{Preparing the jatropha meal}

Jatropha curcas seeds were planted in the city of Luxor, Egypt. The seeds were milled, and the oil was taken out by hexane as solvent (Hawash et al., 2008) in the Oils' Unit at National Research Centre in Egypt to get jatropha meal. After removal, the meal was air-dried to $90 \%$ DM and treated with heat to $150^{\circ} \mathrm{C}$ for an hour in an oven to use in sheep rations.

\subsection{Animals, rations and feeding procedures}

Twenty-four male Barki lambs with an average weight of $32.9 \pm 0.17 \mathrm{~kg}$ were used in this experiment. Lambs were randomly assigned into four experimental groups, 6 lambs per each and fed at $3 \%$ of live body weight to receive one of the experimental diets for 90 days feeding period as follow:

R1 (control ration): CFM1 (0\% heated jatropha meal (HJM) +Peanut vines hay (PVH)

R2: CFM2 (30\% HJM replacement of cotton seed meal) + PVH;

R3: CFM3 (45\% HJM replacement of cotton seed meal) + PVH;

R4: CFM4 (60\% HJM replacement of cotton seed meal) + PVH.

The rations were fed as a total mixed ration ( $75 \%$ concentrate feed mixtures: $25 \%$ roughage) and mixed before feeding. All day time water was freely available. The formula for experimental concentrate feed mixtures is shown in Table 1 and the composition of the 4 experimental rations is presented in Table 2. Animals were weighed weekly before feeding at 8:00 a.m. to calculate the average LBW, average daily gain, daily FI and calculate feed conversion ( $\mathrm{kg} \mathrm{DMI} / \mathrm{kg}$ gain), feeding costs and economic efficiency were estimated. According to the current market price of 2018, the feeding costs for the various pilot rations were estimated. 
Table 1: Formulation of the experimental concentrate feed mixtures (on DM basis)

\begin{tabular}{lcccc}
\hline Ingredients & CFM1 & CFM2 & CFM3 & CFM4 \\
\hline Yellow corn & 58 & 58 & 58 & 58 \\
Wheat bran & 11 & 11 & 11 & 11 \\
Soybean meal & 7 & 7 & 7 & 7 \\
Cottonseed meal & 20 & 14 & 11 & 8 \\
Jatropha seed meal & 0 & 6 & 9 & 12 \\
Limestone & 2.2 & 2.2 & 2.2 & 2.2 \\
Vitamins and minerals mix ${ }^{1}$ & 0.1 & 0.1 & 0.1 & 0.1 \\
Common salt & 1 & 1 & 1 & 1 \\
Sodium bicarbonate & 0.5 & 0.5 & 0.5 & 0.5 \\
Toxin binder & 0.2 & 0.2 & 0.2 & 0.2 \\
Total & 100 & 100 & 100 & 100 \\
\hline
\end{tabular}

CFM1: $0 \%$ heated jatropha meal (HJM), CFM2: 30\% HJM replacement of cotton seed meal, CFM3: $45 \%$ HJM replacement of cotton seed meal and CFM4: 60\% HJM replacement of cotton seed meal. ${ }^{1}$ each $3 \mathrm{~kg}$ of vitamins and minerals premix contained; vit A: $4000000 \mathrm{IU}$, vit D3:1000000 IU, vit E: $4000 \mathrm{mg} / \mathrm{kg}, \mathrm{Mg}: 27000 \mathrm{mg} / \mathrm{kg}, \mathrm{S}: 250 \mathrm{mg} / \mathrm{kg}$, Mn: $9858 \mathrm{mg} / \mathrm{kg}$, Se: $134 \mathrm{mg} / \mathrm{kg}, \mathrm{Zn}: 20700 \mathrm{mg} / \mathrm{kg}$, Cu: $1000 \mathrm{mg} / \mathrm{kg}$, I: $600 \mathrm{mg} / \mathrm{kg}$ and Co: $800 \mathrm{mg} / \mathrm{kg}$.

Table 2: Chemical analysis of the tested feeds and the experimental (CFM) rations (on DMbasis)

\begin{tabular}{lccccccc}
\hline Items & \multicolumn{3}{c}{ Tested feeds } & \multicolumn{4}{c}{ Experimental rations } \\
\cline { 2 - 7 } & PVH $^{* * *}$ & HJM* & CSM** & R1 & R2 & R3 & R4 \\
DM & 90.00 & 94.00 & 90.00 & 86.11 & 86.18 & 86.22 & 86.26 \\
OM & 87.00 & 87.80 & 95.00 & 94.56 & 94.40 & 94.30 & 94.20 \\
CP & 12.70 & 22.00 & 26.00 & 13.97 & 13.79 & 13.70 & 13.61 \\
CF & 26.50 & 31.77 & 24.00 & 12.52 & 13.33 & 13.73 & 14.14 \\
EE & 3.64 & 0.98 & 1.50 & 3.20 & 3.22 & 3.23 & 3.24 \\
Ash & 13.00 & 12.20 & 5.00 & 5.44 & 5.60 & 5.70 & 5.80 \\
NFE & 44.16 & 33.05 & 43.50 & 64.87 & 64.06 & 63.64 & 63.21 \\
\hline
\end{tabular}

*HJM: jatropha meal; **CSM: cotton seed meal; ***PVH: peanut vines hay R1: control ration [CFM1 $(0 \%$ heated jatropha meal (HJM) + peanut vine hay $(\mathrm{PVH})]$; R2: [CFM2 (30\% HJM replacement of cotton seed meal) + PVH]; R3: [CFM3 (45\% HJM replacement of cotton seed meal) + PVH] and R4: [CFM4(60\% HJM replacement of cotton seed meal) + PVH.

\subsection{Sampling of rumen fluid}

Digestibility trials were done in our previous work (Alaa et al., 2020) at the end of the digestibility trial, $100 \mathrm{~mL}$ of rumen fluid were individually withdrawn by rubber stomach tube $3 \mathrm{~h}$ after the morning meal. Collected samples were strained through three layers of cheesecloth and $\mathrm{pH}$ value was immediately measured. Strained rumen fluid was stored in glass bottles, then few drops of toluene and paraffin oil were added and stored at $-18{ }^{\circ} \mathrm{C}$ till be used to assess ammonia-nitrogen (NH3-N) and total volatile fatty acids (TVFA's) concentrations.

\subsection{Sampling of blood}

At the end of the digestibility trial, blood samples were individually collected from the jugular vein in a heparinized test tube at $3 \mathrm{~h}$ post-feeding. Blood samples were centrifuged at $5000 \mathrm{rpm}$ for 15 min., blood serum samples were separated into a glass vial and stored at $-18{ }^{\circ} \mathrm{C}$ to assess total protein, albumin, globulin, alanine aminotransferase (ALT), aspartate aminotransferase (AST), urea and creatinine contents.

\subsection{Methods of analysis}

Chemical analyses of the different CFM, peanut vines hay were done according to the standard procedures of AOAC (2005). The rumen fluid samples were used to determine the $\mathrm{pH}, \mathrm{NH} 3-\mathrm{N}$, and volatile fatty acids. Using the Orion Digital Research $\mathrm{pH}$ scale, Model 201 the $\mathrm{pH}$ values of the rumen fluid samples were measured immediately. Total volatile fatty acid concentrations were determined according to Cunniff (1997), while ammonia - nitrogen concentration was measured according to Preston,(1995). Using a specific kit by the Chemistry Auto-analyzer (Olympus AU 400) all biochemical components of blood serum were measured by colorimetric method, Total serum protein was determined according to Witt and Trendelenburg(1982). Albumin was determined according to the 
Tietz (1986) method. By subtracting the albumin value from the total protein value, the globulin plus fibrinogen was calculated. Alanine aminotransferase (ALT) and aspartate aminotransferase (AST) were determined by the methods of Young (1990). Serum creatinine was measured according to Husdan (1968) and blood urea was determined according to Patton and Grouch (1977).

\subsection{Economical value}

Based on free-market prices in 2018 of feed ingredients, economic efficiency was calculated as the ratio between income (income from gain) and cost of feed consumed (concentrate feed mixture, jatropha meal and peanut vines hay) and cost of the physical treatment. Economic efficiency of each of the diets was defined as LE returned for one LE invested in the feed.

\subsection{Statistically analyzed data}

Data were statistically analyzed according to SAS (1998). The significance among treatment means was tested by Duncan's Multiple Range Test Duncan (1955). The statistical model used as follows:

$\mathrm{Yij}=\mu+\mathrm{Ti}+\mathrm{eij}$

where:

Yij: the observation,

$\mu$ : the overall mean,

Ti: the treatment effect, eij: the experimental error.

\section{Results}

\subsection{Growth performance}

Average daily weight gain (Table.3) was significantly $(\mathrm{P}<0.05)$ higher for lambs fed R1 and R2 followed by R3 and R4 groups. However, no significant difference was detected between R1 (control) and the R2 (30\% heated jatropha meal), also between R3 (45\% heated jatropha meal) and the R4 (60\% heated jatropha meal). The best performance parameters of the animals in both the R1 and R2 groups, which increased the body's growth and supported the improvement of animal productivity and performance. The best growth response was shown by $\mathrm{R} 2$ and the worst was by R4. In the same trend, R1 and R2 had higher total body weight and growth rate compared with R3 and R4.

Table 3: Effect of the experimental rations on lambs on growth performance and feed conversion

\begin{tabular}{|c|c|c|c|c|c|c|}
\hline \multirow[b]{2}{*}{ Item } & \multicolumn{4}{|c|}{ Experimental rations } & \multirow{2}{*}{$\pm \mathbf{S E}$} & \multirow{2}{*}{ Sig } \\
\hline & $\mathbf{R}_{1}$ & $\mathbf{R}_{\mathbf{2}}$ & $\mathbf{R}_{3}$ & $\mathbf{R}_{4}$ & & \\
\hline Initial body weight( kg) & 33.07 & 33.00 & 33.07 & 32.77 & 1.52 & $\mathrm{NS}$ \\
\hline Final body weight (kg) & $50.41^{\mathrm{a}}$ & $50.20^{\mathrm{a}}$ & $44.96^{\mathrm{b}}$ & $42.61^{\mathrm{b}}$ & 1.72 & $*$ \\
\hline Total body weight gain (Kg) & $17.34^{\mathrm{a}}$ & $17.20^{\mathrm{a}}$ & $11.89^{\mathrm{b}}$ & $9.84^{\mathrm{b}}$ & 1.03 & $*$ \\
\hline Average daily gain (g) & $192.67^{\mathrm{a}}$ & $191.11^{\mathrm{a}}$ & $132.11^{\mathrm{b}}$ & $109.33^{\mathrm{b}}$ & 12.38 & $*$ \\
\hline Growth rate $(\%) * * *$ & $52.43^{\mathrm{a}}$ & $52.12^{\mathrm{a}}$ & $35.95^{\mathrm{ab}}$ & $30.03^{\mathrm{b}}$ & 2.33 & $*$ \\
\hline Concentrate DMI (g/h/d) & 983.00 & 953.00 & 794.00 & 712.00 & 68.58 & - \\
\hline Roughage DMI(g/h/d) & 328.00 & 317.00 & 265.00 & 237.00 & 22.86 & - \\
\hline Total DMI (g/h/d) & 1311.0 & 1270.0 & 1059.0 & 949.00 & 91.45 & - \\
\hline TDNI $(g / h / d)$ & $910.62^{\mathrm{a}}$ & $853.44^{\mathrm{b}}$ & $684.54^{\mathrm{c}}$ & $618.37^{\mathrm{d}}$ & 36.03 & $*$ \\
\hline DCPI (g/h/d) & $114.1^{\mathrm{a}}$ & $107.1^{\mathrm{b}}$ & $84.3^{c}$ & $71.7^{\mathrm{d}}$ & 5.22 & $*$ \\
\hline Feed conversion ratio (kg DMI/ kg gain) & $6.80^{\mathrm{b}}$ & $6.65^{b}$ & $8.02^{\mathrm{a}}$ & $8.68^{\mathrm{a}}$ & 0.61 & $*$ \\
\hline TDNI /kg gain & $4.73^{b}$ & $4.47^{\mathrm{b}}$ & $5.18^{\mathrm{a}}$ & $5.66^{\mathrm{a}}$ & 0.40 & * \\
\hline $\mathrm{DCPI} / \mathrm{kg}$ gain & $0.59^{\mathrm{bc}}$ & $0.56^{\mathrm{c}}$ & $0.64^{\mathrm{ab}}$ & $0.66^{\mathrm{a}}$ & 0.01 & $*$ \\
\hline
\end{tabular}

Letters mean in the same row within each treatment having different superscripts differ significantly atP $<0.05$. SE: Standard error of the mean. NS: Non-significant. *: P<0.05.***Total B .W.gain (kg)/ Initial B. W. (kg) x 100.

\subsection{Feed intake and feed conversion}

Data in Table (3) indicated that there were liner decreases in the intake, $g / \mathrm{h} / \mathrm{d}$, of concentrate, roughage and total dry with increasing HJM level in the experimental rations. And the lowest feed intake recorded with R4 being, 712, 237 and $949 \mathrm{~g} / \mathrm{h} / \mathrm{d}$. respectively for concentrate DMI, roughage DMI and total DMI following by R3 (794, 265 and $1059 \mathrm{~g} / \mathrm{h} / \mathrm{d})$ then R2 (953, 317 and $1270 \mathrm{~g} / \mathrm{h} / \mathrm{d})$, in 
the same order. Feed conversion in as Kg dry matter intake/ kg gain indicated significant differences among different rations. R2 recorded the best feed conversion ration being $6.65 \mathrm{~kg} \mathrm{DMI} / \mathrm{kg}$ gain with no significant difference with R1 being $6.80 \mathrm{~kg}$ DMI/ $\mathrm{kg}$ gain.

\subsection{Rumen fluid parameters}

The $\mathrm{pH}$ value at $3 \mathrm{~h}$ post-feeding was not significantly affected by the inclusion of heated jatropha meal $(\mathrm{HJM})$ in rations of growing lambs (Table 4). While, higher $(\mathrm{P}<0.05)$ TVFA's values were indicated after $3 \mathrm{~h}$ post-feeding when lambs fed either control ration or those fed ration contained $30 \%$ HJM. The highest TVFA's value $(7.87 \mathrm{meq} / 100 \mathrm{~mL})$ was recorded in R1 and decreased gradually to $7.10 \mathrm{meq} / 100 \mathrm{~mL}$ in $\mathrm{R} 2$ compared to $5.33 \mathrm{meq} / 100 \mathrm{~mL}$ in $\mathrm{R} 3$ and the lowest value $(3.43 \mathrm{meq} / 100 \mathrm{~mL})$ was noted in R4. Data showed that lambs fed control $(\mathrm{R} 1)$ had the highest $(\mathrm{P}<0.05)$ concentration of NH3-N (31.5 mg/100 mL), with no significant differences with R2 $(24.85 \mathrm{mg} / 100 \mathrm{~mL})$ and R3 $(16.57$ $\mathrm{mg} / 100 \mathrm{~mL}$ ). However, R4 recorded the lowest NH3-N concentration being $8.40 \mathrm{mg} / 100 \mathrm{~mL}$.

Table 4: Effect of experimental rations on rumen liquor at $3 \mathrm{~h}$ post-feeding

\begin{tabular}{|c|c|c|c|c|c|c|}
\hline \multirow{2}{*}{ Item } & \multicolumn{4}{|c|}{ The experimental rations } & \multirow[b]{2}{*}{$\pm \mathbf{S E}$} & \multirow[b]{2}{*}{ Sig. } \\
\hline & $\mathbf{R}_{1}$ & $\mathbf{R}_{2}$ & $\mathbf{R}_{\mathbf{3}}$ & $\mathbf{R}_{4}$ & & \\
\hline pH & 6.27 & 6.00 & 6.17 & 6.10 & 0.07 & NS \\
\hline TVFA's(meq/100mL) & $7.87^{\mathrm{a}}$ & $7.10^{\mathrm{ab}}$ & $5.33^{\mathrm{bc}}$ & $3.43^{c}$ & 0.59 & $*$ \\
\hline $\mathrm{NH}_{3}-\mathrm{N}(\mathrm{mg} / 100 \mathrm{~mL})$ & $31.5^{\mathrm{a}}$ & $24.85^{\mathrm{a}}$ & $16.57^{\mathrm{ab}}$ & $8.40^{\mathrm{b}}$ & 3.27 & $*$ \\
\hline
\end{tabular}

Letters mean in the same row with different superscripts are different at $(\mathrm{P}<0.05),{ }^{*}$ Significant at $(\mathrm{p}<0.05)$ and NS: NonSignificant.

\subsection{Blood parameters}

Data of hemato-biochemical parameters are presented in Table 5. Results showed that the concentration of serum total protein, globulin and urea didn't significantly affect the inclusion of HJM in rations (R2, R3 and R4) of growing lambs compared with control (R1). On the other hand, albumin and creatinine concentration significantly differed $(\mathrm{P}<0.05)$ between the different groups. The average creatinine $(\mathrm{mg} / \mathrm{dL})$ concentration in the serum of experimental animals fed on R1 had the lowest value compared with others. AST and ALT was an indicator of liver functions showed significant differences among different rations.

Table 5: Effect of the experimental rations on blood parameters

\begin{tabular}{|c|c|c|c|c|c|c|}
\hline \multirow[b]{2}{*}{ Item } & \multicolumn{5}{|c|}{ The experimental rations } & \multirow[b]{2}{*}{ Sig. } \\
\hline & $\mathbf{R}_{1}$ & $\mathbf{R}_{2}$ & $\mathbf{R}_{3}$ & $\mathbf{R}_{4}$ & $\pm \mathbf{S E}$ & \\
\hline Total protein (g/dL) & 5.25 & 6.45 & 6.02 & 6.25 & 0.250 & $\mathrm{NS}$ \\
\hline Albumin (g/dL) & $2.14^{\mathrm{b}}$ & $2.71^{\mathrm{a}}$ & $2.28^{\mathrm{b}}$ & $2.46^{\mathrm{ab}}$ & 0.08 & $*$ \\
\hline Globulin (g/dL) & 3.09 & 3.74 & 3.74 & 3.79 & 0.18 & NS \\
\hline $\mathrm{A} / \mathrm{G}$ ratio & 0.69 & 0.72 & 0.61 & 0.65 & 0.08 & NS \\
\hline \multicolumn{7}{|c|}{ Kidney function } \\
\hline Urea (mg/dL) & 35.70 & 31.50 & 30.36 & 27.26 & 2.20 & NS \\
\hline Creatinine (mg/dL) & $0.85^{\mathrm{b}}$ & $1.12^{\mathrm{a}}$ & $0.98^{\mathrm{ab}}$ & $1.04^{\mathrm{ab}}$ & 0.045 & $*$ \\
\hline \multicolumn{7}{|c|}{ Liver function } \\
\hline $\operatorname{AST}(\mathbf{u} / \mathbf{l})$ & $69.35^{\mathrm{b}}$ & $74.13^{\mathrm{a}}$ & $70.90^{\mathrm{b}}$ & $68.46^{\mathrm{b}}$ & 3.93 & $*$ \\
\hline $\operatorname{ALT}(u / \mathbf{l})$ & $24.20^{\mathrm{ab}}$ & $27.45^{\mathrm{a}}$ & $19.07^{\mathrm{bc}}$ & $17.77^{\mathrm{c}}$ & 1.41 & $*$ \\
\hline
\end{tabular}

Letters mean in the same row with different superscripts are different at $(\mathrm{P}<0.05)$. SE: Standard error of the mean. NS: Non-Significant at

$(\mathrm{P}<0.05) . \mathrm{A} / \mathrm{G}=$ Albumin / Globulin. (AST) Aspartate transaminase, (ALT) Alanine transaminase.

\subsection{Economic efficiency}

Based on the difference in both growth rate and feeding cost per animal, the economic efficiency as affected by using HJM as a source of protein is presented in Table (6). As a result of replacing cottonseed meal by jatropha meal, the average feed cost and total cost were decreased being (335.23 and 2315.23 L.E/h), (271.94 and 2256.14 L.E/h.) and (237.02 and 2203.22 L.E/h.), respectively for R2, R3 and R4 compared to (364.51 and 2348.71 L.E/h.) for R1, in the same order. The highest net revenue (696.77 L.E.) was recorded with R2 followed by R1, R3 then R4 being, 675.89, 441.46 and 353.38 L.E., respectively. In the same trend, economic efficiency was higher in R2 being $30.10 \%$, as compared 
with R1 (28.78\%), however, R3 and R4 recorded the lowest economic efficiency (19.57 and 16.04\%, respectively). The relative economic efficiency reflects the improvement with R2 being $104.59 \%$ compared to 68 and $55.73 \%$ with R3 and R4, respectively.

Table 6: Effect of the experimental rations on economic efficiency

\begin{tabular}{|c|c|c|c|c|}
\hline \multirow[t]{2}{*}{ Item } & \multicolumn{4}{|c|}{ The experimental rations } \\
\hline & $\mathbf{R}_{1}$ & $\mathbf{R}_{2}$ & $\mathbf{R}_{3}$ & $\mathbf{R}_{4}$ \\
\hline Purchase cost (L.E./head) ${ }^{1}$ & 1984.2 & 1980.0 & 1984.2 & 1966.2 \\
\hline CFM cost (L.E./head) & 314.33 & 286.73 & 231.39 & 200.76 \\
\hline PVH cost (L.E./head) & 50.18 & 48.50 & 40.55 & 36.26 \\
\hline Feed cost (L.E./head) $)^{2}$ & 364.51 & 335.23 & 271.94 & 237.02 \\
\hline Total cost (L.E./head) ${ }^{3}$ & 2348.71 & 2315.23 & 2256.14 & 2203.22 \\
\hline Selling income (L.E./head) ${ }^{4}$ & 3024.60 & 3012.00 & 2697.60 & 2556.60 \\
\hline Net revenue (L.E./head) ${ }^{5}$ & 675.89 & 696.77 & 441.46 & 353.38 \\
\hline Economic efficiency $(\%)^{6}$ & 28.78 & 30.10 & 19.57 & 16.04 \\
\hline Relative economic efficiency $(\%)^{7}$ & 100 & 104.59 & 68.00 & 55.73 \\
\hline
\end{tabular}

CFM: concentrate feed mixture, PVH: peanut vines hay, ${ }^{1}$ Initial body weight $\times$ price of one $\mathrm{kg}(60 \mathrm{LE}),{ }^{2} \mathrm{Calculated}$ according to the local price in 2018 (3553, 3343, 3238, 3133 L.E./ton for CFM1,CFM2, CFM3 and CFM4, respectively) and $1700 \mathrm{LE} /$ ton for DPV; ${ }^{3}$ Include the fixed, management and feed costs; ${ }^{4}$ final bodyweight $\times$ price of one kg at selling (60 L.E.); ${ }^{5}$ Sellingincome - total cost; ${ }^{6} \mathrm{Net}$ revenue/total cost $\times 100 ;{ }^{7}$ Economic efficiency for treatment/economic efficiency for control, assuming that relative economic efficiency of the control group equals 100.

\section{Discussion}

The results in this study are in agreement with those obtained by (Katole et al. 2011;Gidenne et al., 2012) who indicated a decrease in weight gain with the treatments containing heated jatropha cake because of the reduction in feed intake and less palatability of the rations containing heated jatropha cake, or might be due to other biochemical and metabolic alterations or may be attributed to the level of other anti-nutritional factors which were not detoxified by the heat (Begg and Gaskin, 1994) and by treating jatropha with chemical treatment (Katole., 2007). Similarly, Deshpande (2012) observed a reduction in body weight of sheep and dairy cows fed on processed jatropha meal because of low digestibility and absorption of nutrients may. Also, Li et al. (2018) showed a decrease in average daily gain, average daily feed intake and gain-to-intake ratio as a result of SBM substitution with heated jatropha meal in growing pigs. However, Belewu et al. (2010) it was found that jatropha is rich in zinc, which plays an important role in animal performance and that goats fed on jatropha improved rumen bypass protein, making it available to the animal for production purposes. (El-Sisy et al. 2008; HumannZiehank et al., 2008) explained that lambs fed jatropha containing zinc that is involved in the formation and functioning of thyrotropin hormone, which has an indirect role and effect on thyroid function, essential fatty acids and carbohydrate metabolism, protein synthesis and reduces energy release, which encourages the consumption of diet. The weight gain observed in R1and R2 might be due to the higher intake of nitrogen and energy. The decrease in weight gain with R3 and R4 treatments may be attributed to the reduction in feed intake being 1059 and $949 \mathrm{~g}$, respectively compared to $1311 \mathrm{~g}$ in R1 (control). Malviya et al. (2011) observed better performance in rabbits fed 50\% jatropha seed meal as a replacement of soybean meal, which may be due to the amino acid balance in the diet which reflects higher growth. The amino acid composition of jatropha seeds is excellent regarding a precursor. ElZelaky et al. (2011) reported that lambs fed jatropha had higher body weight during the first 4 to 6 months of age, but the differences in body weight were reduced with increasing feeding period. However, Abo El-Fadel et al. (2011) it was found that lambs fed on jatropha and without jatropha gave equal values in live body weight.

The lower intake may be a sign of temperate poisoning, from which it can be concluded that the process of removing toxic substances should result in the full extraction of phorbol ester. Besides, is possible that the taste, aroma and other anti-nutritional factors of jatropha meal. The highest TDMI with $\mathrm{R} 1$, probably because the combination was palatable. This suggests that lambs would benefit more from being fed $\mathrm{R} 1$ in approximately this proportion. This makes biological sense in terms of nutrient density of the ration because it suggests that an animal would tend to consume more of the diet to derive more of the needed $\mathrm{N}$ for biological activities. There were no significant differences between experimental rations (R1and R2) concerning the average daily feed intake. These results could be due to the positive 
effect of heat treatment and the replacement ratio in the diet. These results agree with (Abo El-Fadel et al., 2011; Belewu et al., 2010) who reported that feeding treated jatropha reduced feed consumption and digestion in goats. A similar reduction in DM intake of concentrate was also reported by Singh et al. (2006) when deoiled cake fed to rams. Katole et al. (2013) found a reduction in dietary nutrient consumption in goat diets contained jatropha treated with 5 to $10 \mathrm{~g}$ of sodium chloride or calcium hydroxide/ kg JM. Da Silva et al. (2015) found that the addition of processed jatropha cake in the diets of Holstein heifers affected the intake of all nutrients.

The improvement in feed conversion ratio for lambs fed rations contained R1 and R2 might be due to enhanced utilization compared with R3 and R4 rations as a result of the increase in the added level of heated jatropha meal. An observed depression in DM intake in the rams fed the processed jatropha meal in comparison with those consumed control diet (Singh et al., 2006; Katole et al., 2013). The presence of anti-nutritional factors and poor digestion of protein and energy limits the bioavailability of nutrients and thus ultimately lead to impair growth. The observed difference in the animals' growth responses may be attributed to several factors such as acceptance of diets, palatability, protein and energy digestion at rations and the presence of toxic and anti-nutritional factors (Makkar $e t$ al., 1997; Aregheore et al., 2003). The presence of phorbol esters in these diets and the undesirable properties of a jatropha meal in terms of taste, aroma and texture may have significant negative effects on the feed intake.

The results in this study are harmonious with Katole et al. (2010) who found that the concentration of TVFA's was higher $(\mathrm{P}<0.05)$ in the control group compared with groups fed jatropha meal. The deamination process in the rumen may have produced less ammonia from the diets relative to the control, probably due to the nature and quality of their dietary protein. According to Ranjah (1980), the concentration of ammonia produced in the rumen fluid depends on the amount and dissolution of the protein fed to animals. The utilization efficiency of NH3-N produced in the rumen depends on urea recycling, the balance of the bacterial load, and the amount of by-pass protein. It may be that the protein moiety of the R3 and R4 groups was less soluble than that of the control. That also meant that more rumen ammonia would be produced as the nitrogen intake increased in R1 and R2. On the other hand, the decrease in N intake in R3 and R4 may be the reason for the lower concentration of NH3-N in the rumen. Similarly, Katole et al. (2010) reported a decrease in the concentration of ruminal NH3-N $(p<0.05)$ with concentrate feed mixture containing raw and jatropha treated with sodium chloride, which explained by reducing the degradation of feed or slow release of NH3-N by rumen microbes and/ or inhibition of residual toxins. Tjakradidjaja et al. (2012) reported no adverse effects on ration fermentation and digestion as a result of the addition of jatropha meal up to $3 \%(\mathrm{v} / \mathrm{w})$.

Results obtained indicated that the serum total protein had no significant difference with R1 compared with the other rations. Abdel Gadir et al. (2003) observed that the kids' lambs received 0.25 $\mathrm{g} / \mathrm{kg}$ Jatropha curcas seeds per day had lower total protein concentration than control, also found that was liver toxicity and liver failure may due to the low concentration in total serum proteins. Besides, Belewu et al. (2010) observed increases in urea and creatinine concentration in African goats fed treated Jatropha curcas seeds. Creatinine and urea concentrations were within the normal ranges in the different groups. Adeyemi et al. (2001) noted decreases in concentrations of serum total protein, albumin and globulin, and an increase in serum creatinine level as a result of the substitution of boiled jatropha seeds by $7.8,15.6,23.4$ and $31.2 \%$ of nutritional groundnut cake in poultry feed diet. Kaneko et al. (1997) found an increase in AST activity when Anglo-Nubian goats fed on jatropha meal, although the enzyme activity and levels were in the normal range. Abdel Gadir et al. (2003) showed no significant changes in serum ALT activity in some kids' lambs who received Jatropha curcas seeds at 0.25 to $1 \mathrm{~g} /$ $\mathrm{kg}$ per day. Sirisha et al. (2008) observed significant increases in ALT, AST and bilirubin levels. For cows and heifers, Kirubakaran et al. (2009) reported a decrease in serum ALT and AST levels than those previously detected. Especially in the liver, increasing the activity of these enzymes indicates cell structure damage (Kaneko et al., 1997). Some authors found that ALT activity was decreased but AST activity was increased with the addition of jatropha in sheep and rabbit diets. (Katole et al., 2011; Akhigbe et al., 2009).

The reduction in feed cost and total costs with R3 and R4 may be due to the lower price HJM included in the feed formation for R3 and R4 compared with R1 and R2. Abd El-Rahman et al. (2011) found that total feed cost decreased with increasing the replacement of cumin seed meal with jatropha seed meal compared with control. This decrease was due to the lower cost for jatropha seed meal (54 
\$/ton) compared with $252 \$ /$ ton for cumin seed meal. The results also found an improvement in economic efficiency and relative economic efficiency with lambs fed rations contained $30 \%$ heated jatropha meal. This result is in harmony with Belewu et al. (2010) who reported that the efficiency of feed use was improved by adding jatropha to diets because it had positive effects. Also, Abo El-Fadel et al. (2011) found a reduction in the average daily feed cost by $17.24 \%$ than the control group with replacing $50 \%$ soybean meal with biologically treated jatropha meal, and both economic efficiency and economic return were improved by compared with the control group. This result is in harmony with ElZelaky et al. (2011) who also reported that jatropha addition in the ration, resulted in an improvement occurred in both economic efficiency and economic return by 10.14 and $6.5 \%$, respectively than control ration.

\section{Conclusion}

Heated JM can be used as one of the sources of protein in diets so that the replacement percentages do not exceed $30 \%$ of the protein source. And can be used to be in a fattening lambs diet without any adverse effects on growth performance and blood parameters. Short-term nutrition of jatropha meal integrated diets indicates similar to those in the control group. In future studies, longterm feeding experiments are warranted to monitor any adverse effects of heated jatropha meal feed on the carcass characteristics of ruminants.

\section{Abbreviations}

AAP: Amino Acid Profile; ADG: Average daily gain; ALT: Alanine aminotransferase; AOAC: Association of Official Analytical Chemists; AST; Aspartate aminotransferase; CF: Crude fiber; CFM: Complete feed mixtures; CP: Crude protein; DCP: Digestible crude protein; DM: Dry matter; DMI: Dry matter intake; DN: Digestible nitrogen; EE: Ether extract; FC: Feed conversion; FI: Feed intake; HJM: Heated jatropha meal; JSM: Jatropha seed meal; L.E.: Egyptian Pound; LBW: Live body weight; NFE: Nitrogen-free extract; NH3-N: Ammonia nitrogen; OM: Organic matter; PVH: Peanut vines hay; TDNI; Total digestible nutrients /intake; TVFAs: Total volatile fatty acids.

\section{Declarations \\ Authors' contributions}

YAAE: Co-operated in the plan of work and field work, collected samples, prepared data, statistical analysis, writing and revision of the manuscript and follow up the publication with the journal. WMAG: Co-operated in writing, revision and statistical analysis of the manuscript. MAH Co-operated in the revision of the manuscript. HHA: Co-operated in the plan of work and revision of the manuscript. AEMM: Co-operated in revision of the manuscript. AYKE: Co-operated in field work, collected samples, laboratory analysis. All authors read and approved the final manuscript.

\section{Acknowledgments}

Our deep thanks to Sheep Experiment Unit, Research and Production Station, Abd El-Moneam Riad Village, National Research Centre for saving facilities that make this work possible.

\section{References}

Abd El-Rahman, H.H., A.A. Abedo, F.M. Salman, M.I. Mohamed and M.M. Shoukry, 2011. Partial substitution of cumin seed meal by jatropha meal as a potential protein source for feed. African J. Biotech, 10: 15456-15461.

Abdel Gadir, W.S., T.O. Ousa, W.E.M. Ali, S.M.A. EI Badwi and S.E.I. Adam, 2003. Comparative toxicity of Croton maerostaehys, Jatropha curcas and Piper abyssiniea in Nubian goats. Small Ruminant Research, 48: 61-67.

Abo El-Fadel, M.H., A.M. Hussein, and A.H. Mohamed, 2011. Incorporation Jatropha curcas meal on lambs ration and it's effect on lambs performance. J. of American Sci., 7 (2): 129-132.

Adam, S.E.I., and M. Magzoub, 1975. A toxicity of Jatropha curcas for goats. Toxicology, 4: 347-354

Aderibigbe, A.O., C.O.L.E. Johnson, H.P.S. Makkar, K. Becker, and N. Foidl, 1997. Chemical composition and effect of heat on organic matter- and nitrogen-degradability and some ant nutritional components of jatropha meal. Anim Feed Sci. Technol., 67: 223-243 
Adeyemi, O.A., M.O. Balogun, and O.E. Fasina, 2001. Response of finishing broilers to graded levels of boiled Jatropha seeds. Indian J. of Anim. Sci., 71: 800-803.

Akhigbe, A.O., M. Idu, E.S. Orhue, J.E. Ataman, and S.O. Ehimwenman, 2009. Effect of jatropha tanjorensis J.L. Ellis and Soroja leaves in rabbits: biochemistry and ultrasonography. Res. J. Med. Plant, 3 (1): 29-33.

Alaa, Y.K.E., H.H. Abd El-Rahman, Y.A.A. El-Nomeary, M.A. Hanafy, and A.E.M. Mahmoud, 2020. In vitro evaluation and in vivo digestibility of physically, chemically and biologically treated jatropha meal. Pak. J. Biol. Sci. 23(5):638-649.

Annongu, A.A., M.A. Belewu, and J.K. Joseph, 2010. Potentials of Jatropha seeds as substitute protein in nutrition of poultry. Res. J. Anim. Sci., 4 (1): 1-4.

Antyev, M., B. Yakubu, Y.H. Aliyara, and R.J. Wafar, 2017. Effects of processing methods of jatropha curcas seed meal on growth performance and blood profile of broiler finisher chickens. Asian Res. J. of Agric., 4(4): 1-9

AOAC, 2005. Association of Official Analytical Chemists, Official Methods of Analysis, $18^{\text {th }}$ ed Washington DC USA.

Apori, S.O., 1988. Replacement value of yam peels for maize in diets of White Fulani Cattle". Ph.D. Thesis Univ of Ibadan: Ibadan, Nigeria.

Aregheore, E.M., K. Becker and H.P.S. Makkar, 2003. Detoxification of a toxic variety of Jatropha curcas using heat and chemical treatments, and preliminary nutritional evaluation with rats. S. Pac. J. Nat. Sci., 21: 50-56.

Begg, J., and T. Gaskin, 1994. Jatropha curcas L." National Toxicology Group: New Zealand.

Belewu, M.A., K.Y. Belewu, and F.O. Ogunsola, 2010. Nutritive value of dietary fungi treated Jatropha curcas kernel cake: voluntary intake, growth and digestibility coefficient of goat. Agric. Biol. J. N. Am., 1: 135-138

Belewu1, M.A., and R. Sam, 2010. Solid-state fermentation of Jatropha curcas kernel cake: Proximate composition and ant-nutritional components. J of Yeast and Fungal Res., 1(3): 44-46

Cunniff, P.A., 1997. Official Methods of Analysis of AOAC International. 16 ${ }^{\text {th }}$ Edn Association of Official Analytical Chemists Arlington USA ISBN: 0-935584-54-4.

Da Silva, C.E.L., M. Sandro, C.L. da Silva, F.C.M. Rogério, T. Maria, E. Danilo, L.T.G.R. de Carvalho João, F. Ana, W. da Costae, and S. Euclésio, 2015. Chemical Composition and Cytotoxic Activity of the Root Essential Oil from Jatropharibifolia (Pohl) Baill (Euphorbiaceae). J BrazChemSoc 26: $233-238$

Deshpande, K.Y., 2012. Nutritional evaluation of detoxified Jatropha curcas meal in sheep and dairy cattle. Ph.D. Thesis submitted to Indian Veterinary Research Institute (Deemed University), Izatnagar- 243122, U.P. India.

Duncan, D.B., 1955. Multiple range and multiple F test. Biometrics, 11: 1.

Duwa, H., E.O. Oyawoye, and A.A. Njidda, 2002. Effect of processing methods on the utilization of sorrel seed meal by broilers. Pakistan J. of Nut., 11 (1): 38-46.

El- Zelaky, O.A., Kh.A.H. EI Mohamed, B.K. Mohamed, and H.A.M. EL-Sisy, 2011. Productive and reproductive performance of Rahmani male lambs fed rations containing jatrophacake. Egy. J. of Sheep \& Goat Sci. 6 (2):15 - 24.

EL-Sisy, G.A., A.M.A. Abdel-Razek, A.A. Younis, A.M. Ghallab, and M.S.S. Abdou, 2008. Effect of dietary zinc or selenium supplementation on some reproductive hormonal levels in male Baladi goats. Global Veterinaria, 2(2): 46-50.

Gidenne, T., S. Combes, and L. Fortune-Lamothe, 2012. Feed intake limitation strategies for the growing rabbit. Effect of feeding behavior, welfare, performance, digestive physiology and health; A Review PubMed gov (Animal), 6 (9): 1047-1019

Hass, W., and M. Mittelbach, 2000. Detoxification experiments with the seed oil from Jatropha curcas L, Industrial Crop and Products, 12: 111-118

Hawash, S., N. Kamal, and G. El Diwani, 2008. Egyptian jatropha oil extraction for biodiesel production. AFINIDAD LXV 538: 470-5

Humann-Ziehank, E., M. Ganter, I. Hennig Pauka, and A. Binder, 2008. Trace mineral status and liver and blood parameters in sheep without mineral supply compared to local roe deer (CapreolusCapreolus) populations. Small Ruminant Res., 75:185- 191

Husdan, H., 1968. Chemical determination of creatinine with deproteinization. Clin Chem, 14:222 
Kaneko, J.J., J.W. Harvey and M.L. Bruss, 1997. Clinical Biochemistry of Domestic Animals.5th Edn. Academic Press San Diego USA.

Katole, S., S.K. Saha, V.R.B. Sastry, M.H. Lade, and B. Prakash, 2013. Intake, blood metabolites and hormonal profile in goat fed processed Jatropha (Jatropha curcas) meal. Trop Anim. Health and Prod., 45: 1563-1569.

Katole, S., S.K. Saha, V.R.B. Sastry, M.H. Lade, and B. Prakash, 2011. Intake, blood metabolites and hormonal profile in sheep fed processed Jatropha (Jatropha curcas) meal. Anim. Feed Sci. and Tech., 170: 21-26.

Katole, S., S.K. Saha, V.R.B. Sastry, S.S. Zadbuke, M.H. Lade, and K. Sharma, 2010. Effect of inclusion of raw and processed jatropha (Jatropha curcas) meal at graded levels in concentrate mixture on in vitro rumen fermentation. Indian Veterinary Journal, 87(7): 678-680.

Katole, S.B., 2007. Comparative Nutritional performance of sheep and goat fed with diets containing processed Jatropha (Jatropha curcus) meal. MVSc thesis submitted to Indian Veterinary Research Institute (Deemed University) Izatnagar- 243122 U.P. India.

Kirubakaran A, J. Shailendra, and R.K. Nema, 2009. The PEM fuel cell system with DC/DC boost converter: Design, modeling and simulation. Int J of Recent Trends in Engineering, 1 (3): 157161.

Li, Y., L. Chen, Y. Zhang, J. Wu, Y. Lin, Z. Fang, L. Che, S. Xu, and D. Wu, 2018. Substitution of soybean meal with detoxified Jatropha curcas kernel meal: Effects on performance, nutrient utilization, and meat edibility of growing pigs. Asian-Australas, J. Anim. Sci., 31:888-898

Makkar, H.P.S., and K. Becker, 1997. Potential of $J$. Curcas seed meal as a protein supplement to livestock feed, constraints to its utilization and possible strategies to overcome constraints. In: Gubitz GM Mittelbach MTeabiM editors. Biofuels and industrial products from Jatropha curcas. Managua, Nicaragua: DBV fur die Technische Universitat Graz, 190-205.

Makkar, H.P.S., G. Francis and K. Becker, 2008. Protein concentration from jatropha carcass crewpressed seed cake and toxic and ant-nutritional factors in protein concentrate. Journal of Science Food and Agriculture, 88: 1542-1548

Malachek, J.C., and F.D. Provenza, 1981. Feeding Behaviour and Nutrition of Goats on Rangelands". Proceedings, International Symposium on Nutrition and Systems of Goat Feeding. P MorandFehr ABourbouze and M. De Simiane (eds.).12- 15 May 1981. Tours, France. 411-428.

Malviya, S.N., R. Malakar, M. Yadav, A. Mishra, and A. Tiwari, 2011. Estimation and characterization of protein present in seed extract of Jatropha curcas. Advance Research in Pharmaceuticals and Biology, 1 (1):35-38.

Michael, K.G., O.A. Sogbesan, L.U. Onyia, and S.M. Shallangwa, 2019. Nutritional evaluation of processed Jatropha curcas seed meals. J. Agric Food Sci., 7(6): 131-136

Moore, K., S. Greenhut, and W. Vendrame, 2011. Greenhouse production of jatropha, a potential biofuel crop. Hort Technology, 21: 193- 197

Ojediran, T.K., Y.A. Adisa, S.A. Yusuf, and I.A. Emiola, 2014. Nutritional evaluation of processed Jatropha curcas kernel meal: Effect on growth performance of broiler chicks. Journal of Animal Science Advances, 4(11):1110-1121.

Patton, F.G., and S.R. Grouch, 1977. Colorimetric determination of urea. Anal. Chem. 49:468

Preston, T.R., 1995. Biological and chemical analytical methods. In: Preston TR Tropical animal feeding: a manual for research workers. Rome: FAO chap. 9: 191-264.

Preston, T.R., and R.A. Leng, 1986. Matching livestock systems to available feed resources. ILCA: Addis Ababa, Ethiopia. 200.

Rajpoot, R.L., O.P.S. Sengar, and S.N. Singh, 1981. Energy and protein in Goat nutrition". Proceedings, International Symposium on Nutrition and Systems of Goat Feeding: Vol. 1. P. Morand- Fehr A Bourbouze, and M De Simiane (eds.). 12-15 May 1981 Tours France ITOVICINRA. 101-124

Rakshit, K.D., J. Darukeshwara, K.R. Raj, K. Narasimhamurthy, P. Saibaba, and S. Bhagya, 2008. Toxicity studies of detoxified Jatropha meal (Jatropha curcas) in rats. Food ChemToxicol 46, $3621-3625$.

Ranjah, S.K., 1980. Animal nutrition in the Tropics.2nd Revised edn. VikasPubl House Pvt Ltd New Delhi, India

SAS, 1998. Statistical Analysis System. SAS User's Guide Statistics. SAS InstInc Ed Cary NC 
Singh, P., V.R.B. Sastry, A.K. Garg, A.K. Sharma, G.R. Singh, and D.K. Agrawal, 2006. Effect of long term feeding of expeller pressed and solvent extracted karanj (Pongamiapinnata) seed cake on the performance of rams. Animal Feed Science and Technology, 126: 157-68

Sirisha, P., A.A. Kumar, B. Padmaja, and M. Lakshman, 2008. Haematobiochemical changes in Jatrophadeoiled seed cake (Jatropha curcas) induced toxicity in broiler chicken and their amelioration. Indian Journal of Veterinary Pathology, 32: 47-51

Sudake, K.S., S. Parnerkar, S.S. Shankhpal, V. Boraniya, and S.B. Katole, 2013. Feed intake, digestibility, rumen fermentation pattern and blood biochemical profile of growing crossbred calves fed lime treated Jatropha (Jatropha curcas) cake. Lives Res. Inter., 1(1): 8-17

Tietz, N.W., 1986. A method for the rapid determination of albumin of blood plasma. P.589 in Textbook of Clinical Chemistry WB Saunders Company Philadelphia

Tjakradidjaja, A.S., K.G. Wiryawan, and M. Afrianti, 2012. Fermentability and digestibility of ration containing crude curcin extract of Jatropha curcas seed meal. ${ }^{\text {nd }}$ Int. Sem Anim Ind Jakarta, 406 $-412$

Witt, I., and C. Trendelenburg, 1982. A method for the rapid determination of total protein plasma. J Clin Bio chem., 20: 235

Young, D.S., 1990. Effects of drugs on clinical laboratory tests. $3^{\text {rd }}$ Ed 3:6 